\title{
A cross sectional study to compare effects of mechanical dilatation and sublingual misoprostol on induction of labor in a tertiary level government hospital
}

\author{
Laxmi Maru, Vibhuti Thakur*, Kavisha Lambhate
}

Department of Obstetrics \& Gynecology, MGM Medical College \& M. Y. Hospital, Indore, MP, India

Received: 09 February 2016

Accepted: 19 February 2016

*Correspondence:

Dr. Vibhuti Thakur,

E-mail: drvibhuti01@gmail.com

Copyright: ( ) the author(s), publisher and licensee Medip Academy. This is an open-access article distributed under the terms of the Creative Commons Attribution Non-Commercial License, which permits unrestricted non-commercial use, distribution, and reproduction in any medium, provided the original work is properly cited.

\begin{abstract}
Background: To compare sublingual misoprostol versus mechanical dilatation of the cervix with Foley' catheter in induction of labor, the need for other method of augmentation of labor like oxytocin infusion, to find out maternal outcome and perinatal outcome and to find out rate of caesarean section in both the groups.

Methods: The study was carried out in the department of obstetrics and gynaecology, M.Y. Hospital Indore, on pregnancies with an indication for induction of labor either with mechanical dilatation or with misoprostol. Two groups are made each of 100 cases. One group is induced with Foley' catheter and other with 25 mcg misoprostol sublingually. Both groups are compared on the basis of age, parity, indication of induction, duration of cervical ripening and delivery, need of oxytocin augmentation. Maternal and foetal outcomes are also compared.

Results: Most of the cases in both groups were primigravida, belong to 20-25 year of age group. Most cases were induced for postdatism followed by PIH. Induction delivery interval was short in cases received misoprostol. Also misoprostol group required less oxytocin augmentation, and has significant low rate of caesarean section. There was no significant difference in both cases in terms of maternal and foetal complications.

Conclusions: Misoprostol is very safe and effective drug for induction of labour. It has property of collagenous remodelling of cervix along with stimulation of uterine contraction. Hence its induction-delivery interval is short with little requirement of oxytocin augmentation. Rate of failed induction is also low.
\end{abstract}

Keywords: Sublingual misoprostol, Mechanical dilatation of the cervix, Foley' catheter, Induction of labor

\section{INTRODUCTION}

Induction of labour is a common procedure in obstetrics. ${ }^{1,2}$ It is done with the aim of achieving vaginal delivery whenever continuation of pregnancy present a threat to the life or wellbeing of the mother and her unborn child. Modern obstetrics techniques have greatly increased the safety and reliability of induction of labour so that it can be performed with greater confidence of success. The spectrum of indications has increased to the point, where the slightest risk to the mother or fetus is considered as sufficient indication for induction of labour. Timely induction reduces perinatal and maternal morbidity and mortality. In developed countries, induction of labour accounts for about $25 \%$ of all deliveries. In developing countries, the rates vary; lower in some regions, and high in some areas. ${ }^{3}$ African countries generally have lower induction rates compared with Latin American and Asian countries. ${ }^{3}$ A study by the WHO global survey on maternal and perinatal health in 24 countries reported that induction of labour accounted for $9.6 \%$ of all deliveries. ${ }^{3}$ The incidence of labour induction was also noted to be on the increase. ${ }^{3}$

Indications for induction of labour include immediate conditions such as severe preeclampsia or ruptured 
membranes. The other common medical and obstetric indications include membrane rupture without labour, gestational hypertension, postdated pregnancy, oligohydraminos, non-reassuring fetal status, intrauterine growth restriction, chronic hypertension, and diabetes. ${ }^{4}$

Different methods are used for labour induction but none of the available methods of induction of labour is free of associated medical risks. The most common methods of labour induction when the status of cervix is unfavourable involve intravaginal use of misoprostol, transcervical insertion of Foley's catheter, and insertion of prostaglandin gel whereas with a ripe cervix oxytocin may be administered intravenously. Mechanical methods are among the oldest and most important approaches used for induction of labour. ${ }^{5,6}$

\section{Aims and objectives}

- Comparative study of sublingual misoprostol versus mechanical dilatation of the cervix with Foley' catheter in induction of labour.

- The need for other method of augmentation of labour like oxytocin infusion.

- To find out maternal outcome and perinatal outcome.

- To find out rate of caesarean section in both the groups.

\section{METHODS}

The study was carried out in the department of obstetrics and gynecology, M.Y. Hospital Indore, M.P on pregnancies with an indication for induction of labour either with mechanical dilatation or with misoprostol. This is a comparative study.

\section{Inclusion criteria}

- $\quad$ Singleton pregnancy

- Vertex presentation

- Gestational age greater than or equal to 36 completed weeks

- Bishop's score less than 6

- No Cephalopelvic disproportion

- No history of bronchial asthma, glaucoma, serious cardiovascular disorders, renal diseases, metabolic or endocrinal disorders

\section{Exclusion criteria}

- Previous uterine scar

- Non-vertex presentation

- Ante partum hemorrhage, CPD

- Placenta previa

- Case with history of asthma, glaucoma

- Known hypersensitivity to prostaglandins
Pregnant women were divided in 2 groups, in $1^{\text {st }}$ group 100 cases induced with Mechanical dilatation and in $2^{\text {nd }}$ group 100 cases induced with Misoprostol.

Detailed history of the case was recorded with special reference to age, parity, menstrual history and obstetrical history. Gestational age was calculated from the first day of last menstrual period. General examination donetemperature, pulse, BP, respiratory rate was done. Complete obstetric examination performed; (a) Per abdomen-fundal height of uterus, FHS, presentation, engaged/non-engaged head; (b) Per vaginal-pelvis assessed, cervical status recorded-position, length, consistency and effacement of cervix is note along with the descent of the presenting part.

Preliminary laboratory investigations done $-\mathrm{Hb}$, blood group, urine analysis, ultrasound.

Cases are divided in 2 groups (100 in each group).

Group 1 induced with mechanical dilatation. 18 size Foley's catheter was introduced through cervix using sterile technique with aid of speculum and sponge holding forceps and $40 \mathrm{ml}$ distilled water was instilled into balloon.

Group 2 induced with misoprostol, 25 microgram sublingually.

Subsequently doses were given after every 4 hours till case developed adequate uterine contraction pattern (3 or more uterine contractions in 10 minutes lasting more than 40 seconds), the cervix reach $3 \mathrm{~cm}$ or more of dilatation, $100 \%$ effacement or spontaneous rupture of membranes or up to maximum of 3 doses.

In both groups, as per vaginum examination was done every 3 hours to assess Bishop's score and progress of labour. All patients were monitored clinically for progress of labour and fetal wellbeing. Occurrence of abnormal uterine contraction was documented. After 2 hours of artificial rupture of membranes further need for intravenous oxytocin in the misoprostol group for augmentation of labour or increasing the dose of oxytocin in the Foley catheter group was individualized depending upon the uterine contraction.

\section{Primary outcome measures}

1. Time interval from induction to onset of labor

2. Time taken from initiation of therapy to delivery

3. Rate of failure to induce labour, defined as no vaginal delivery within 48 hours

4. Number of cases that landed up into caesarian section. 
Secondary outcome measures

1. Associated obstetric and intrapartum complications

2. Postpartum complications (6 weeks)

3. Neonatal complications (28 days)

\section{Statistical analysis}

The groups will be compared by using chi square test and unpaired student $\mathrm{t}$ test.

\section{RESULTS}

Table 1: Age wise distribution of cases.

\begin{tabular}{|llllll|}
\hline $\begin{array}{l}\text { Age } \\
\text { (years) }\end{array}$ & $\begin{array}{l}\text { Group } \\
\text { I MD }\end{array}$ & $\%$ & $\begin{array}{l}\text { Group } \\
\text { II MP }\end{array}$ & $\%$ & Total \\
\hline$<25$ & 77 & 77.0 & 80 & 80.0 & 157 \\
\hline $25-30$ & 23 & 23.0 & 16 & 16.0 & 39 \\
\hline$>30$ & 0 & 0.0 & 4 & 4.0 & 4 \\
\hline Total & 100 & 100.0 & 100 & 100.0 & 200 \\
\hline
\end{tabular}

Above table shows most of the patients age is between 20-25 year in all groups, only 4 patients in group II are more than 30 years.

Table 2: Distribution of cases according to parity.

\begin{tabular}{|llllll|}
\hline Gravidity & $\begin{array}{l}\text { Group } \\
\text { I MDD }\end{array}$ & $\%$ & $\begin{array}{l}\text { Group II } \\
\text { MP }\end{array}$ & $\%$ & Total \\
\hline G1 & 62 & 62.0 & 51 & 51.0 & 113 \\
\hline G2 & 29 & 29.0 & 44 & 44.0 & 73 \\
\hline G3 & 9 & 9.0 & 5 & 5.0 & 14 \\
\hline Total & 100 & 100 & 100 & 100 & 200 \\
\hline
\end{tabular}

Table 3: Distribution of cases according to indications of induction of labour.

\begin{tabular}{|lllll|}
\hline \multirow{2}{*}{ Indications } & Group & \multicolumn{3}{l|}{ II (MP) } \\
& I (MD) & & $\mathbf{n = 1 0 0}$ & \% \\
\cline { 2 - 5 } & $\mathbf{n = 1 0 0}$ & $\mathbf{\%}$ & 0 & 0.0 \\
\hline Hydramnios & 8 & 8.0 & 6 & 6.0 \\
\hline IUD & 7 & 7.0 & 6 & 16.0 \\
\hline IUGR & 9 & 9.0 & 16 & 4.0 \\
\hline Oligo & 1 & 1.0 & 4 & 47.0 \\
\hline PDP & 45 & 45.0 & 47 & 27.0 \\
\hline PE+HTN & 30 & 30.0 & 27 & \\
\hline
\end{tabular}

Above table shows preeclampsia and HTN and prolonged pregnancy are the most common indications for induction which is $30 \%$ and $45 \%$ in group I and $27 \%$ and $47 \%$ in group II respectively.

Table 4 shows most of the patients in group I have taken 4-7 hours from induction to cervical ripening.
Most of the patients in group II have taken 2-5 hours from induction to cervical ripening, which is significant with $\mathrm{p}$.

Table 4: Distribution of cases according to induction to cervical ripening interval.

\begin{tabular}{|lllll|}
\hline $\begin{array}{l}\text { Cervical ripening } \\
\text { duration }\end{array}$ & Group & & II (MP) \\
\hline $2-3$ & $\mathbf{n = 1 0 0}$ & $\mathbf{\%}$ & $\mathbf{n = 1 0 0}$ & $\mathbf{\%}$ \\
\hline $4-5$ & 14 & 14.0 & 27 & 27.0 \\
\hline $6-7$ & 35 & 35.0 & 37 & 37.0 \\
\hline $8-9$ & 33 & 33.0 & 21 & 21.0 \\
\hline $10-11$ & 8 & 8.0 & 9 & 9.0 \\
\hline $12-13$ & 2 & 2.0 & 0 & 0.0 \\
\hline $14-15$ & 2 & 2.0 & 6 & 6.0 \\
\hline & 6 & 6.0 & 0 & 0.0 \\
\hline Mean & Group 1 & & Group 2 & \\
\hline SD & 6.09 & & 5.24 & \\
\hline p value & 2.83 & & 2.47 & \\
\hline
\end{tabular}

The mean duration was significantly more in group-I.

Table 5: Distribution of cases according to Bishops score.

\begin{tabular}{|l|llll|}
\hline \multirow{2}{*}{ Bishop score } & Group & & & \\
& I (MD) & & (MP) \\
\hline 2 & $\mathbf{n = 1 0 0}$ & $\mathbf{\%}$ & $\mathbf{n = 1 0 0}$ & $\mathbf{\%}$ \\
\hline 3 & 42 & 42 & 48 & 48 \\
\hline 4 & 58 & 58 & 51 & 51 \\
\hline
\end{tabular}

Above table shows most of the patients in both the groups came with bishop's score 2 and 3 at the time of admission.

Table 6 : Distribution of cases according to duration from cervical ripening to delivery.

\begin{tabular}{|c|c|c|c|c|}
\hline \multirow{3}{*}{$\begin{array}{l}\text { Duration } \\
\text { CRIP to DEL }\end{array}$} & \multicolumn{4}{|l|}{ Group } \\
\hline & \multicolumn{2}{|l|}{ I (MD) } & \multicolumn{2}{|c|}{ II (MP) } \\
\hline & $n=100$ & $\%$ & $n=100$ & $\%$ \\
\hline $2-3$ & 2 & 2.0 & 6 & 6.0 \\
\hline $4-5$ & 2 & 2.0 & 6 & 6.0 \\
\hline $6-7$ & 33 & 33.0 & 37 & 37.0 \\
\hline $8-9$ & 19 & 19.0 & 20 & 20.0 \\
\hline $10-11$ & 19 & 19.0 & 17 & 17.0 \\
\hline $12-13$ & 6 & 6.0 & 8 & 8.0 \\
\hline $14-15$ & 11 & 11.0 & 3 & 3.0 \\
\hline $16-17$ & 6 & 6.0 & 2 & 2.0 \\
\hline \multirow[t]{2}{*}{$18-19$} & 2 & 2.0 & 1 & 1.0 \\
\hline & \multicolumn{2}{|c|}{ Group 1} & \multicolumn{2}{|l|}{ Group 2} \\
\hline Mean & \multicolumn{2}{|l|}{9.47} & \multicolumn{2}{|l|}{8.1} \\
\hline SD & \multicolumn{2}{|l|}{3.57} & \multicolumn{2}{|l|}{3.08} \\
\hline p value & \multicolumn{4}{|l|}{0.0037} \\
\hline
\end{tabular}


The mean duration was significantly more in group-I.

Above table shows most of the patients in group I require $7-12$ hours $(71 \%)$ from induction to delivery, most of the patients in group II $(63 \%)$ require 4-9 hours from induction to delivery.

Table 7: Comparison of cases according to requirement of oxytocin.

\begin{tabular}{|llllll|}
\hline $\begin{array}{l}\text { Oxytocin } \\
\text { require- } \\
\text { ment }\end{array}$ & $\begin{array}{l}\text { Group } \\
\text { I MID }\end{array}$ & $\begin{array}{l}\% \\
\text { Group I }\end{array}$ & $\begin{array}{l}\text { Group } \\
\text { II MD }\end{array}$ & $\begin{array}{l}\% \\
\text { Group }\end{array}$ & Total \\
\hline No & 6 & 6.0 & 17 & 17.0 & 23 \\
\hline Yes & 94 & 94.0 & 83 & 83.0 & 177 \\
\hline Total & 100 & 100 & 100 & 100 & 200 \\
\hline$p=0.027$ & & & & & \\
\hline
\end{tabular}

Significantly higher number of patients of group-I required oxytocin.

Above table shows $94 \%$ in group I and $83 \%$ in group II require oxytocin.

Table 8: Distribution of cases according to mode of delivery.

\begin{tabular}{|lllll|}
\hline \multirow{2}{*}{ Mode of delivery } & Group & & \\
& I(MD) & & II (MP) \\
\hline Caesarean section & n=100 & \% & n=100 & \% \\
\hline Forceps and ventouse & 5 & 22 & 10 & 10 \\
\hline Vaginal & 73 & 5 & 3 & 3 \\
\hline
\end{tabular}

$\mathrm{p}=0.033$

$22(22 \%)$ of group-1 had caesarean delivery, statistically significant.

Above table shows rate of caesarean section is more in group as compared to group II.

Table 9: Comparison of cases according to maternal complications.

\begin{tabular}{|lllll|}
\hline Maternal & Group & & \\
complications & I (MD) & \multicolumn{3}{l|}{ II (MP) } \\
\hline Fever & $\mathbf{n = 1 0 0}$ & $\mathbf{\%}$ & $\mathbf{n = 1 0 0}$ & \% \\
\hline Nausea and vomiting & 2 & 2 & 1 & 1 \\
\hline UTI & 0 & 0 & 12 & 12 \\
\hline Nil & 6 & 6 & 1 & 1 \\
\hline
\end{tabular}

Above table shows nausea and vomiting is the most common maternal complication and is more common in group II. $\mathrm{p}=0.098$

$14 \%$ women of group-2 had complications but statistically not significant.
Table 10: Comparison of cases according to neonatal complications.

\begin{tabular}{|l|llll|}
\hline \multirow{2}{*}{$\begin{array}{l}\text { Neonatal } \\
\text { complications }\end{array}$} & I (MD) & II (MP) & \\
\hline Jaundice & n=100 & \% & n=100 & \% \\
\hline Meconium passage & 1 & 1 & 4 & 4 \\
\hline Nil & 2 & 2 & 9 & 9 \\
\hline
\end{tabular}

Above table shows most common complication is meconium passage which is more seen in group II.

Table 11: Distribution of cases according to APGAR score.

\begin{tabular}{|lllll|}
\hline $\begin{array}{l}\text { APGAR } \\
\text { score }\end{array}$ & $\begin{array}{l}\text { Group } \\
\text { I MD }\end{array}$ & $\begin{array}{l}\% \\
\text { Group I }\end{array}$ & $\begin{array}{l}\text { Group } \\
\text { II MIP }\end{array}$ & $\begin{array}{l}\text { \% Group } \\
\text { II }\end{array}$ \\
\hline Not normal & 18 & 18 & 13 & 13 \\
\hline Normal & 82 & 82 & 87 & 87 \\
\hline Total & 100 & 100 & 100 & 100 \\
\hline
\end{tabular}

\section{DISCUSSION}

Induction of labour is an integral component of all maternity practice and is often taken up in the interest of the mother and the fetus. Labour induction in the presence of an unfavorable cervix is associated with an increased likelihood of prolonged labour and increased incidence of caesarean section. The present study was carried out in the department of obstetrics and gynaecology, M.Y. Hospital Indore, M.P. in 200 cases to compare sublingual misoprostol and mechanical dilatation in cervical ripening for induction of labour.

Present study showed that prolonged pregnancy and hypertension are the commonest indication for induction of labour in both the groups. Similar findings were seen in the study of Sciscione et al. ${ }^{7}$ Our study shows that misoprostol group takes less time in induction compare to Foley catheter, which is significant with $\mathrm{p}=0.02$.

Sciscione et al compared transcervical Foley catheter to intravginal misoprostol for preinduction cervical ripening, showed that misoprostol group takes less time in induction compare to Foley catheter which is similar to our study. ${ }^{7}$ Our findings were similar to Promila et al, Sheikher et al, Filho et al and Roudsari et al who also found significantly shorter induction to delivery interval in misoprostol group. ${ }^{8-11}$ Present study shows most of the patients in Foleys group require $7-12$ hours (71\%) from cervical ripening to delivery, most of the patients in misoprostol group (63\%) require 4-9 hours from cervical ripening to delivery, which is significant with $\mathrm{p}=0.0037$. Our study is not in accordance with Prager et al who found that induction to delivery interval was significantly shorter in Foley catheter group as compared to misoprostol and $\mathrm{PGE}_{2}{ }^{12}$ Present study shows vaginal delivery is common mode of delivery in both the groups. 
The rate of CS is more in Foleys group (22\%) as compared to misoprostol group, which is statistically significant with $\mathrm{p}=0.033$. Present study shows that oxytocin augmentation is required in both the groups, it is $94 \%$ in group I and $83 \%$ in group II i.e. significantly higher in Foley group with $\mathrm{p}$ value $=0.027$. Bhatiyani et al used Foley catheter for preinduction cervical priming in 52 patients and found the procedure to be safe and effective for induction in patients with unripe cervices with mean induction to delivery time of 8 hours and change in Bishop's score by 4 hour. ${ }^{13}$ They concluded, however, that ripening with Foley catheter subsequently requires augmentation with oxytocin. Present study shows nausea and vomiting were the most common maternal complications in misoprostol group but statistically not significant. Roudsari et al found hyperstimulation occurring more frequently in the misoprostol group. ${ }^{11}$ Chung et al in their study found that hyperstimulation occurred in $33.3 \%$ women in misoprostol group and $11.1 \%$ women in Foley catheter group. ${ }^{14}$ In the present study, there was no significant difference in Apgar score at 1 or 5 minute, hyperbilirubinemia, septicemia and passage of meconium in either group.

\section{CONCLUSION}

The secret of success in labour induction lies in replicating the process of spontaneous parturition as closely as possible. It should be considered when the benefits of earlier delivery outweigh the potential risks to the mother and baby associated with induction of labour and prolongation of pregnancy. Mechanical methods (Foley's catheter) to ripen the cervix have the advantage of low cost, stability at room effects. It is very cheap but takes more time from induction to labour. PGE1 (misoprostol) when applied sublingually provides to be an effective and better method for cervical ripening and induction of labour when combined with judiciously timed amniotomy achieving less time in induction of labour in women with unfavourable cervix.

In conclusion, Misoprostol is long acting and very potent and is a promising drug for labour induction.

Funding: No funding sources Conflict of interest: None declared

Ethical approval: The study was approved by the Institutional Ethics Committee

\section{REFERENCES}

1. Laws PJ, Sullivan EA. Australia's Mothers and Babies 2002. AIHW Cat. No. PER 28. Sydney: AIHW National Perinatal Statistics Unit (Perinatal Statistics Series No. 15), 2004.

2. National Collaborating Centre for Women's and Children's Health. Induction of Labour. London, UK: RCOG Press. 2008.
3. WHO Global Survey on Maternal and Perinatal Health. Induction of labour data. Geneva; World health Organization. 2010.

4. Mozurkewich E, Chilimigras J, Koepke E, Keeton K, King VJ. Indications for induction of labour: a bestevidence review. BJOG: An International Journal of Obstetrics and Gynaecology. 2009;116(5):626-36.

5. Jozwiak SM, Oude RK, Benthem M, van Beek E, Dijksterhuis MG, de Graaf IM. Foley catheter versus vaginal prostaglandin E2 gel for induction of labour at term (PROBAAT trial): an open-label, randomised controlled trial. The Lancet. 2011;378:2095-103.

6. Orhue AA, Ande AB. Induction of labor. In: Okpere EE, ed. Clinical Obstetrics. Benin: University of Benin Press. 2004.

7. Sciscione AC, Nguyen L, Manley J, Pollock M, Maas B, Colmorgen G. A randomized comparison of transcervical Foley catheter to intravaginal misoprostol for preinduction cervical ripening. Obstet Gynecol. 2001;97(4):603-7.

8. Promila J, Kaur GB, Bala T. A comparison of vaginal misoprostol versus Foley's catheter with oxytocin for induction of labor. The Journal of Obstetrics and Gynecology of India. 2007;57(1):427.

9. Sheikher C, Suri N, Kholi U. Comparative evaluation of oral misoprostol, vaginal misoprostol and intracervical Folley's catheter for induction of labour at term. JK Science. 2009;11(2):75-7.

10. Filho OBM, Albuquerque RM, Cecatti JG. A randomized controlled trial comparing vaginal misoprostol versus foley catheter plus oxytocin for labor induction. Acta Obstetricia et Gynecologica Scandinavica. 2010;89(8):1045-52.

11. Roudsari FV, Ayati S, Ghasemi M. Comparison of vaginal misoprostol with Foley catheter for cervical ripening and induction of labor. Iranian Journal of Pharmaceutical Research. 2011;10(1):149-54.

12. Prager M, Eneroth-Grimfors E, Edlund M, Marions L. A randomised controlled trial of intravaginal dinoprostone, intravaginal misoprostol and transcervical balloon catheter for labour induction, BJOG: An International Journal of Obstetrics \& Gynaecology. 2008;115(11):1443-50.

13. Bhatiyani BR, Shah PS, Kansaria JJ, Parulekar SV. Induction of labour by Foley's Catheter, http://www.bhj.org/journal/2003_4502_april/ induction_297.htm Accessed on 1/8/2004.

14. Chung JH, Huang WH, Rumney PJ, Garite TJ, Nageotte MP. A prospective randomized controlled trial that compared misoprostol, foley catheter, and combination misoprostol-foley catheter for labor induction. American Journal of Obstetrics and Gynecology. 2003;189(4):1031-5.

Cite this article as: Maru L, Thakur V, Lambhate K. A cross sectional study to compare effects of mechanical dilatation and sublingual misoprostol on induction of labor in a tertiary level government hospital. Int J Reprod Contracept Obstet Gynecol 2016;5:624-8. 